\title{
Comparative Analysis of Water Quality Methods for the Monitoring of Eutrophication Regarding Implementation of WFD in Serbia
}

\author{
Zorica Svirčev', Svetislav Krstić', \\ Jelica Simeunović', Teofil Nakov' ${ }^{2}$, \\ Tamara Dulić
}

\begin{abstract}
Survey of 26 water bodies in Serbia that were found "blooming" at least once during the last 25 years has been conducted in May 2007. Samples were taken for physicchemical analysis, diatom community composition and abundance, and WQI, PantleBuck, IPA and van Dam diatom (OMNIDIA 4.1) indices calculated. Comparative analysis of the obtained results showed that water quality regulations in Serbia are out of date and not approximated to EU regulations, WQI and Pantle-Buck index are not reliable and should not be used in further postulation of WFD eutrophication monitoring system in Serbia, algal monitoring (especially cyanobacteria and diatoms) is highly reliable bio-indication system that reflects the real eutrophication patterns in the sampled water bodies, and that there is an evident trend of water quality deteriorating in almost all examinated ecosystems. "State change approach" is proposed for implementation of WFD eutrophication monitoring system in Serbia that has a significant advance against the "spatial change classification" currently forced by EU legislation.
\end{abstract}

Key words: WFD, eutrophication, monitoring, methods, water quality objectives

\footnotetext{
Department of Biology and Ecology, Faculty of Sciences, Novi Sad, Serbia 2 Institute of Biology, Faculty of Natural Sciences, Skopje, Macedonia
}

\section{Introduction}

Water quality should be defined on the basis of the total biotic and abiotic characteristics of surface waters as a point on a yardstick between water unacceptable for consumption and habitation, and a reference point or a chosen target point, under the current hydrological, chemical and biogeographical conditions (Boon \& Howell, 1997).

Water quality can be defined only by objective, measurable parameters in relation to a reference state of freshwater ecosystem. Parameters used are often still exclusively chemical, although the uses for which water quality is assessed may include drinking water, recreation and ecology. In the countries with a longer history of water quality management, there has been a gradual change from a purely chemical approach to one in which ecological descriptions are included.

Moss et al. (1996) have proposed an array of variables which seem to satisfy these considerations. The array includes: water retention time, maximum depth, conductivity, inflow and lake total phosphorus and nitrogen concentrations, winter inflow nitrate concentration, lake nitrogen, phosphorus ratio, Secchi disc depth, total alkalinity, $\mathrm{pH}$, lake calcium concentration, maximum phytoplankton chlorophyll-a concentration, plant score, and potential for the maintenance of at least one fish species. All of these are easily measurable but examination of existing data sets indicates that at least six evenly distributed samplings will be necessary to obtain values of the current status of most of these within +- $50 \%$ of their true means. The system has three principal classes of water quality and three categories of lake sensitivity to degradation. The water quality classes are based on different ranges of 18 parameters (physical, chemical and biological) indicative of general water conditions. Most of the values are representative for surface and bottom layers and they are averaged either seasonally or specifically for spring and/or summer periods. Among the variables proposed above for the characterization of waters bodies are four key variables that underpin many of the others. These are retention time, conductivity, and inflow total nitrogen and phosphorus concentrations. Most of the parameters mentioned above are directly addressed to the problems in water bodies caused by eutrophication.

Eutrophication is generally understood to refer to enrichment of water systems by nutrient elements, notably nitrogen and phosphorus, and to the enhanced production of algal and higher plant biomass that the added loads stimulate (Reynolds, 1992). Normally, the eutrophication is natural phenomenon, but during the last 2 decades, the word 'eutrophication' has been frequently used to denote the artificial and undesirable addition of plant nutrients to waterbodies (Ryding and Rast, 1989). In some situations, this view can be misleading, since what is undesirable addition to one waterbody may be harmless, or even beneficial, in another waterbody. Nevertheless, eutrophication is most commonly known as the state of a waterbody which is manifested by an intense proliferation of algae and aquatic plants, and their accumulations in the waterbody in vast quantities. OECD (1982) define eutrophication as 'the nutrient enrichment of waters which results in stimulation of an array of symptomatic changes, among which increased production of algae and macrophytes, deterioration of water quality and other symptomatic changes, are found to be undesirable and interfere with water uses'. Eutrophication of standing water bodies is an extremely rare natural condition, and almost always represents an entirely anthropogenic phenomenon. This condition can arise from alterations in land use which lead to increased nutrient release, and the presence in the catchment of substantial quantities of highly concen- 
trated phosphorus in the form of fertilizers or excreta from humans or livestock. It is important to realize, therefore, that water quality in standing water bodies changes through time very quickly.

Using the results obtained by the comprehensive water monitoring field investigations that took place in spring 2007 on a total of 26 water bodies in Serbia, this paper's principle goal is to compare some of the crucial biological and chemical parameters with the EU and domestic water quality criteria, and also to compare several biotic indices regarding their applicability in the regular WFD monitoring system in Serbia.

\section{Investigated sites}

During Spring 2007, a comprehensive field survey of water ecosystems in Serbia, which were found in state of algal "blooming" at least once during the last 25 years (Simeunović et al., 2005). These water bodies belong to: 1) reservoirs for water supply: 1-Ćelije, 2- Bovan, 3- Grliška, 4-Gruža, 5-Garaši, 6-Bukulja; 2) reservoirs for irrigation: 25-Borkovac, 26- Pavlovci; 3) lakes: 7Mrtva Tisa, 15- Provala, 16- Zobnatica, 17Tavanakut, 18-Palić, 19- Ludoš, 24-Koviljski rit,; 4) hydrosistem Danube-Tisa-Danube: 8-DTD Bačko Gradište, 9-DTD Bečej, 11DTD Vrbas, 12- DTD Ruski Krstur, 13- DTD Sombor, 14- DTD Srpski Miletić,and 5) rivers: 10-Krivaja, 20-Tisa Novi Kneževac, 21Srpski Itebej, 22-Tamiš Botoš, 23-Jegrička.

\section{Material and methods}

All physic-chemical parameters were analyzed according to APHA (1992) standards. The analysis were performed in Department of Biology and Ecology, Faculty of Sciences, Novi Sad, using multiparameter apparatus Pastel - UV "SECOMAM".

The Water Quality Index (WQI) was developed by American National Sanitation Foundation as a standard, easy to use, method for detecting the ecological and sanitation water quality range (Mitchell \& William, 1995). Index developed by Pantle and Buck (1955) is widely used to reveal saprobity in standing and running waters.

Measurements of chlorophyll $a$ concentrations (APHA, 1995), as indirect indicator of the intensity of primary production, is based on Felfoldy (1980) scale for detecting the trophic status of the waterbody.

Phosphatase activity index developed by Matavulj (1986) is used as a biochemical parameter for water quality determination. The intensity of the phosphatase activity in the water is directly related to the total organic biodegradable content in the water body, detected as the quantity of transformed substrate (para-nitrophenil phosphate into para-nitrophenol) in $\mu \mathrm{mol}$ per second per $1 \mathrm{dm}^{3}$ volume

Diatoms for this study were collected as epilithic growth on stones, peryphit-

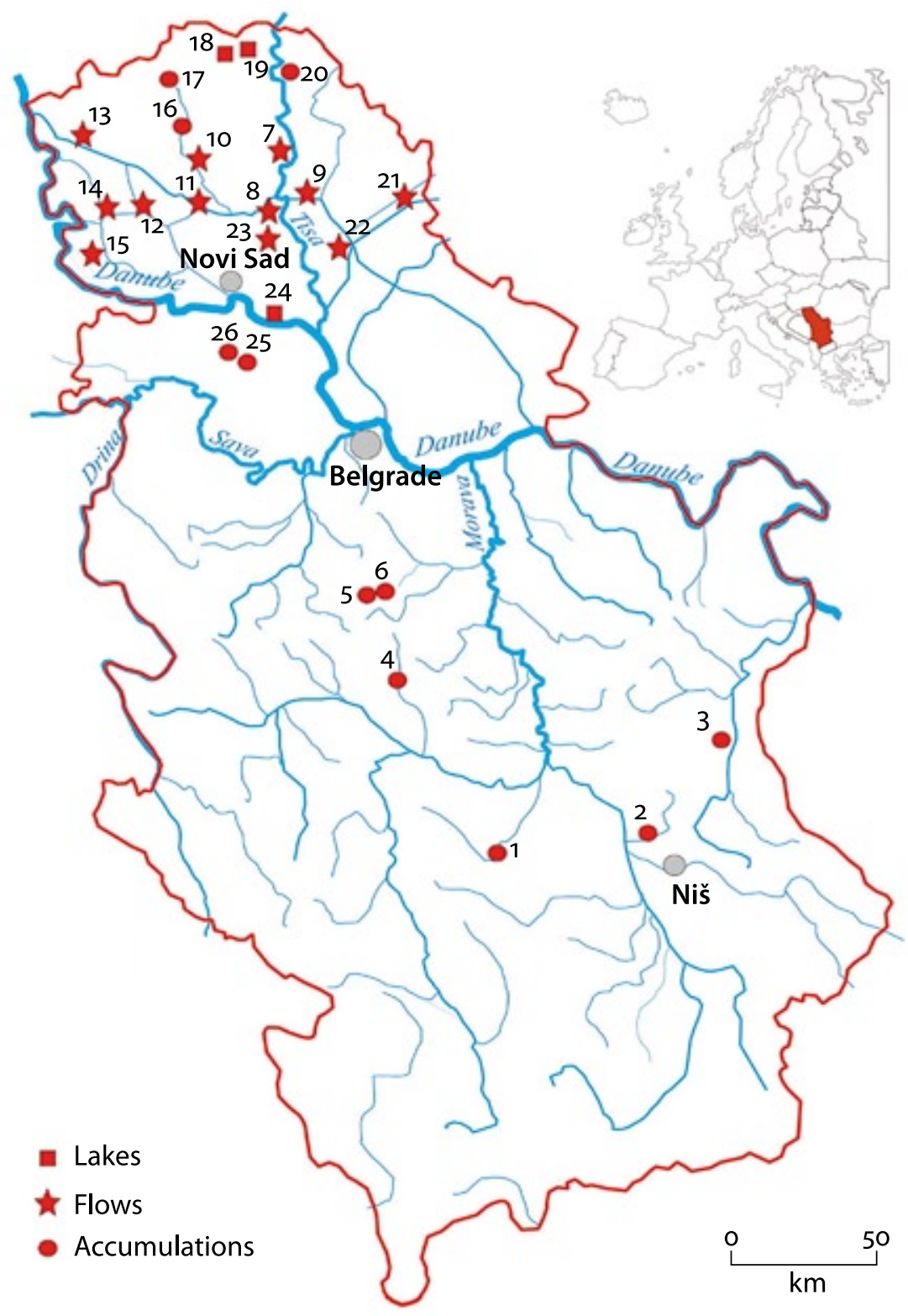

Figure 1 Map of sampled water ecosystems in Serbia during Spring 2007 field survey

ic growth on submerged substrates and as epipsammon or epipelon on the sediments. More than 200 permanent slides by means of slightly modified Krammer and LangeBertalot (1986) method were prepared with complete mixing of sampled diatom flora, aimed for relevant representation of diatom taxa composition and abundance, and mounted in Naphrax. A total of 200 cells per slide were counted on Nikon E-8oo microscope using 1500 times magnification and photomicrographs were taken by Nikon Coolpix 4500 digital camera.

Analysis of the diatom flora composition and abundance was conducted by means of the proposed method by van Dam et al. (1994) and the proposed bio-indicator WFD method by Krstić et al. (2007). Diatom indices were calculated via the OMNIDIA 4.1 software (Lecointe et al., 1993). The software utilizes indicator values for diatom taxa developed by van Dam et al. (1994) for Netherlands, which are consid- ered appropriate for the different ecosystems in Balkan, most important for the purpose of eutrophication monitoring being saprobity and trophy indices developed as shown on the top of the next page.

The Shannon-Weaver (1949) $H^{\prime}$ index is used for the calculation of diatom diversity per sampling site, o being the lowest and 5 the highest taxa diversity.

Water quality classes according to selected physic-chemical parameters were obtained from the valid law regulations in Serbia - Water Classification Regulative (Official gazette of SFRY No.6/78) and cross checked with the classification system used in Germany (Asbaek and Valat$\mathrm{ka}, 2001$ ).

\section{Results and Discussion}

Table 1 represents the obtained results on basic physic-chemical parameters considering eutrophication of the water bodies. Chosen parameters are presented for 


\begin{tabular}{|l|l|l|l|l|}
\hline Saprobity & Water class & Oxygen saturation (\%) & BOD5 (mg I-1) & Trophic state \\
\hline oligosaprobic & I, I-II & $>85$ & $<2$ & 1. Oligotrophic \\
B-mesosaprobic & II & $70-85$ & $2-4$ & 2. Oligo-mesotrophic \\
a-mesosaprobic & III & $25-70$ & $4-13$ & 3. mesotrophic \\
a-meso-polysaprobic & III-IV & $10-25$ & $13-22$ & 4. meso-eutrophic \\
polysaprobic & IV & $<10$ & $>22$ & 5. eutrophic \\
& & & & 6. hyper-eutrophic \\
& & & 7. indifferent \\
\hline
\end{tabular}

detecting the temporal (Spring 2007) eutrophication patterns in monitored water ecosystems, checking the derived biotic indices regarding their applicability for monitoring of the eutrophication, but also in light of WFD water body classification and implementation since all of monitored water ecosystems were found in state of cyanobacterial "blooming" at least once during last 25 years (Simeunović et al., 2005).

From the presented results, it is immediately clear that the relevant water quality regulation in Serbia is out of date and should be approximated to EU regulations (Common Implementation Strategy for WFD, Guidance Document 13 - Overall
Approach to the Classification of Ecological Status and Ecological Potential, 2005). It is also evident that even for the existing water quality parameters in Serbia legislation (like $\mathrm{NH}_{4}{ }^{+}$or $\mathrm{NO}_{3}{ }^{-}$), the proposed water quality range is much lower compared to existing system in Germany (also with the majority of existing systems in EU), and therefore also require revision.

Since WFD (200o) states (WFD Annex $\mathrm{V}$, section 1.4.2.): "For surface water categories, the ecological status classification for the body of water shall be represented by the lower of the values for the biological and physic-chemical monitoring results...", detected classes represent the overall wa- ter quality of examined ecosystems in May 2007, meaning that they belong to II, III-IV or IV water quality class and two of them, Krivaja and Ludoš, even outside the categorization due to extreme ammonia and BOD and COD values.

Table 2 represents the obtained WQI index for the sampled localities, the values of Pantle-Buck (1995) biotic index for saprobity, concentrations of $\mathrm{Chl} a$ and related trophy status of the water ecosystems and Matavulj (1986) index of phosphatase activity (IPA) of the water as a reflection of the total microbial activity for organ ic decomposition. It is very evident that both WQI and Pantle-Buck as indexes do

Table 2 Water Quality Index (WQI), Pantle-Buck (1955) index, concentration of Chl a and related trophy index, and Matavulj (1986) Index of Phosphatase Activity (IPA) for the 26 sampled localities in Serbia, May 2007

\begin{tabular}{|c|c|c|c|c|c|}
\hline Localities & & $\begin{array}{l}\text { WQI } \\
\text { index }\end{array}$ & $\begin{array}{l}\text { Pantle-Buck } \\
\text { index }\end{array}$ & $\begin{array}{l}\text { Chl a conc. } \\
\left(\mathrm{mg} / \mathrm{m}^{3}\right)\end{array}$ & $\begin{array}{c}\text { Matavulj (1986) IPA index } \\
\left(\mu \mathrm{mol} / \mathrm{s} / \mathrm{dm}^{3} \mathrm{pNP}\right) 30^{\circ} \mathrm{C}\end{array}$ \\
\hline 1-Ćelije & 82 & Good & $2.13-\beta$ & 23.56 - meso to eutrophic & 3.75 - IIIA polluted \\
\hline 2- Bovan & 77 & Good & $2.44-\beta$ & 20.28 - meso to eutrophic & 6.32 - IIIB very polluted \\
\hline 3- Grliško Lake & 77 & Good & $2.17-\beta$ & 7.42 - oligo to mesotrophic & 1.39 - II/III medium polluted \\
\hline 4-Gružansko Lake & 74 & Good & $2.56-a$ & 2.89 - oligotrophic & 0.26 - IIA relatively clean \\
\hline 5-Garaši & 62 & Medium & $1.56-\beta$ & 21.36 - meso to eutrophic & 5.64 - IIIB very polluted \\
\hline 6-Bukulja & 84 & Good & $2.29-\beta$ & 1.32 - oligotrophic & 1.81 - II/III medium polluted \\
\hline 7-Mrtva Tisa & 55 & Medium & $2.19-\beta$ & 44.06 - meso to eutrophic & 5.89 - IIIB very polluted \\
\hline 8-DTD Bačko Gradište & 80 & Good & $1.98-\beta$ & 64.08 - eutrophic & 8.84 - III/IV polluted \\
\hline 9-DTD Bečej & 64 & Medium & $2.22-\beta$ & 50.73 - eutrophic & 10.65 - IVA extremely polluted \\
\hline 11-DTD Vrbas & 65 & Medium & $2.17-\beta$ & 11.57 - mesotrophic & 11.53 - IVA extremely polluted \\
\hline 12- DTD Ruski Krstur & 66 & Medium & $2.24-\beta$ & 11.35 - mesotrophic & 6.92 - IIIB very polluted \\
\hline 13-DTD Sombor & 72 & Good & $1.78-\beta$ & 10.68 - mesotrophic & 7.09 - IIIB very polluted \\
\hline 14-DTD Srpski Miletić & 85 & Good & $2.06-\beta$ & 7.12 - oligo to mesotrophic & 7.43 - IIIB very polluted \\
\hline 15-Provala Vajska & 80 & Good & $1.96-\beta$ & 2.00 - oligotrophic & 3.28 - IIIA polluted \\
\hline 16- Zobnatica & 55 & Medium & $2.33-\beta$ & 10.68 - mesotrophic & 3.07 - IIIA polluted \\
\hline 17-Tavankut & 59 & Medium & $2.54-a$ & 5.34 - oligo to mesotrophic & 2.47 - II/III medium polluted \\
\hline 18-Palić & 57 & Medium & $2.56-a$ & 77.43 - eutrophic & 5.86 - IIIB very polluted \\
\hline 19-Ludoš & 55 & Medium & $2.65-a$ & 124.6 - eu to polytrophic & 11.83 - IVA extremely polluted \\
\hline 20-Tisa - Novi Kneževac & 70 & Medium-Good & $2.11-\beta$ & 12.46 - mesotrophic & 1.86 - II/III - medium polluted \\
\hline 23-Jegrička & 61 & Medium & $2.07-\beta$ & 19.22 - mesotrophic & 1.54 - II/III medium polluted \\
\hline 24-Koviljski rit & 72 & Good & $2.34-\beta$ & 17.36 - mesotrophic & 3.97 - IIIA polluted \\
\hline 25-Borkovac & 69 & Medium & $2.23-\beta$ & 12.82 - mesotrophic & 3.39 - IIIA polluted \\
\hline 26-Pavlovci & 63 & Medium & $2.13-\beta$ & 6.41 - oligo to mesotrophic & 3.87 - IIIA polluted \\
\hline
\end{tabular}




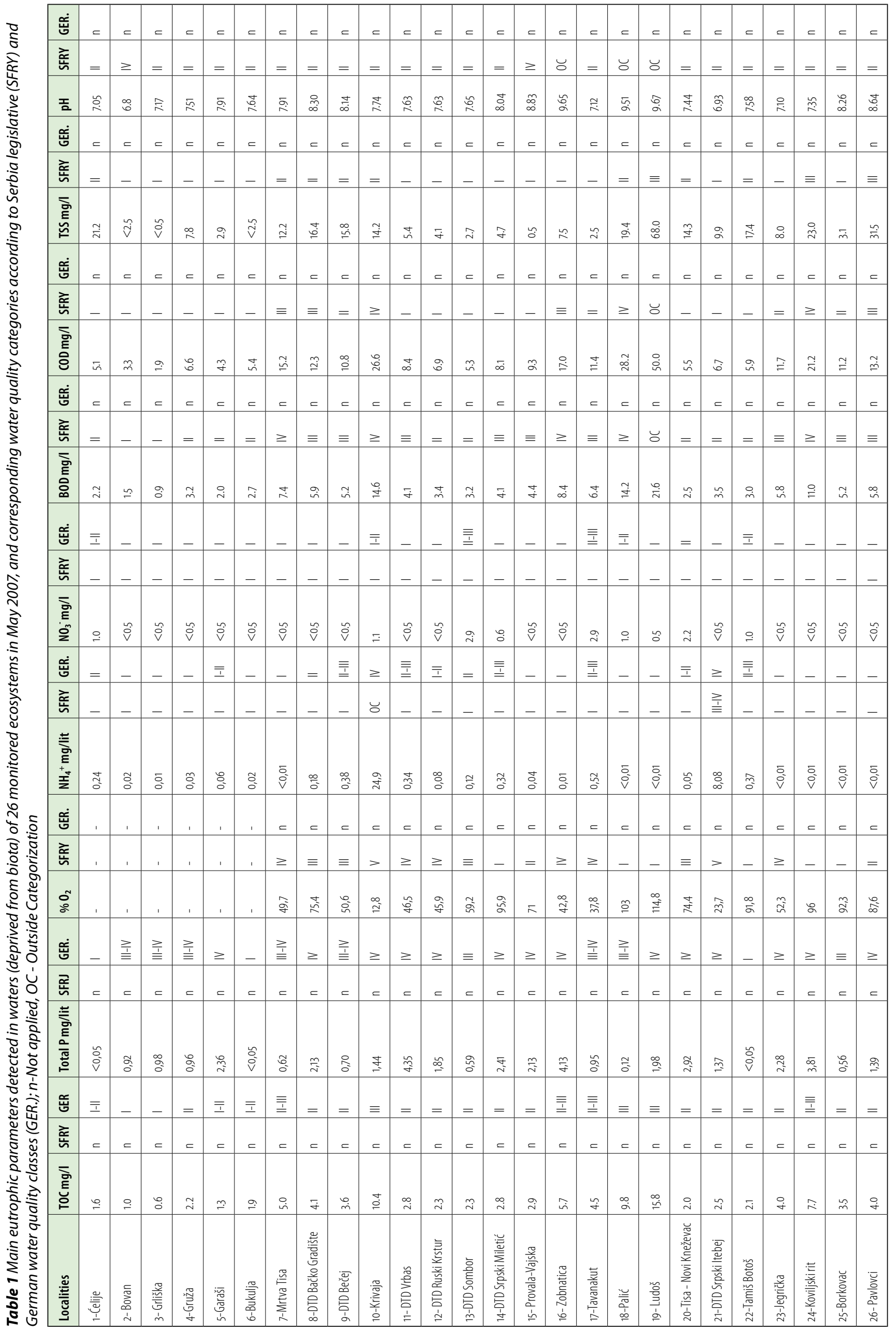


not represent the real water quality state and can be regarded as useless for representation of results and implementation of prolonged monitoring, although regarding WQI (and also Pantle-Buck for that matter) there are still some recent papers (like Veljković and Jovičić, 2006) that promote this index as applicable for some of the most polluted reservoirs in Serbia (like Gruža, Bovan or Grlište) and place these ecosystems in the frame of $75 / 440 / \mathrm{EEC}$ EU directive as suitable for drinking water supply. These findings are in a full agreement with Washington's (1980) opinion on highly unreliable utilization of any mathematical index, other than plain similarity index, for ecological monitoring of aquatic ecosystems, but also in line of Krstić et al. (2007) opinion that biotic indexes, like Pantle-Buck for example, are based on assigning the numeric values to specific taxa for using them in mathematical calculations, what generally underestimates important biological features (like adaptation and evolution), and are consequently rigid and not-applicable.

On the other hand, presented results for Chl $a$ concentrations and IPA index significantly approach the detected real physicchemical situation in sampled ecosystems, although with some uncertainties as well. Based on biological activity, both indica- tors are strongly depended on temporal and spatial environmental characteristics in the time of sampling, but only the IPA index actually presented extremely polluted sites, although failing to detect the increased category in some instances (Gruža reservoir).

In the recent review study, Krstić et al. (2007) have tried to point that algal monitoring, diatoms and cyanobacteria in particular, is the best choice since these primary producers react swiftly and consequently to rapid water quality changes, and if blooming clearly show the advanced stage of water quality deterioration usually marked as "out of category". Diatoms are important contributors of the primary production in aquatic ecosystems (Wetzel, 1983). They can serve as good indicators of the ecological status of surface waters. Therefore, biotic measures have advantages against chemical analyses. Most importantly, they integrate environmental effects (Cox, 1991) reflecting the typical conditions instead of momentary values that can be measured precisely with chemical methods. Diatoms are suggested to be indicators of environmental conditions and can be used successfully in biomonitoring (Round, 1991). Diatom based impact analyses have a long history (Kolkwitz and Marson, 1908; Butcher, 1947). A number of methods (Kelly, 1998; Dell'Uomo, 1996, Rumeau and Coste, 1988; Descy and Coste, 1991; Coste in Cemagref, 1982; Lenoir and Coste, 1996; Prygiel and Coste, 2000) were developed for use of diatoms as bioindicators of changing environment, especially in rivers. The applicability of these indices has been spatially limited, even for rivers, since distribution of species may differ markedly ( $\mathrm{Wu}, 1999)$. As most described diatom indices were developed and applied for running waters, applications for lakes are sporadic and in many cases doubtful.

Conducted analysis of diatom flora composition and abundance on the 26 sampled ecosystems and derived diatom indices presented in Table 3 have clearly confirmed the rapid trend of deterioration of the water quality of almost all surveyed ecosystems. The majority of these ecosystems have been found to be in deep hypertrophy where diatom flora is limited to only few taxa that dominate the habitat sometimes with more than $80 \%$. This fact is a direct consequence of prolonged pressure on these ecosystems, so that diatom diversity is limited to only those taxa that can survive these impacts, and therefore are indicators of high trophy levels, while the presence of diatom species typical for clean waters is sporadic and with very low abun-

Table 3 Results obtained by diatom taxa composition and abundance via OMNIDIA 4.1 software, comments on the diatom assemblages related to water trophy indication according to Krstić et al. (2007) and corresponding micro image of the relevant diatom taxa at the sampling site.

\begin{tabular}{|c|c|c|}
\hline Locality & Comments & Sample image \\
\hline 1 - Ćelije & $\begin{array}{l}\text { Diversity - 4.07; Eutrophic; } \beta \text {-mesosaprobic } \\
\text { Diatom assemblage is represented by Gomphonema minutum (19\%), Navicula } \\
\text { capitatoradiata ( } 12 \% \text { ) and Stephanodiscus rotula (10\%) forming } 41 \% \text { of the total } \\
\text { count. The following Encyonema silesiacum ( } 6 \%) \text { and Fragillaria capucina }(7 \%) \\
\text { add a total of } 54 \% \text { of taxa that prefer eutrophic conditions. High diversity is } \\
\text { represented by a total of } 29 \text { recorded diatom taxa, majority of which belong to } \\
\text { ecosystems with low saprobity values. Conclusion: Celije experiences frequent } \\
\text { inputs of nutrients, but is usually in } \beta \text {-mesosaprobic range of pollution. }\end{array}$ & \\
\hline 2 - Bovan & $\begin{array}{l}\text { Diversity - 2.66; Mesotrophic; } \beta \text {-mesosaprobic } \\
\text { Low diversity is reflected by Fragillaria capucina (37\%), Cymbella caespitosum } \\
(30 \%) \text {, Gomphonema minutum ( } 9 \% \text { ) and Navicula capitatoradiata }(6 \%) \text {, a total } \\
\text { of } 82 \% \text { of the diatom assemblage. The mesotrophic state is largely a result of } \\
\text { high count of F.capucina, but this ecosystem is clearly under intensive stress. } \\
\text { Conclusion: Bovan is losing its } \beta \text {-mesosaprobic range rapidly. }\end{array}$ & \\
\hline 3-Grliška & $\begin{array}{l}\text { Diversity - 3.98; Meso-eutrophic; } \beta \text {-mesosaprobic } \\
\text { Diatom assemblage is represented by planktonic Cyclotella ocellata (29\%), and } \\
\text { epiphytic Navicula radiosa (9\%), Achnantidium minutissimum (7\%), Cymbella } \\
\text { caespitosum (6\%) and Fragillaria capucina (6\%), a total of } 57 \% \text { of eutrophic } \\
\text { taxa. High diversity is represented with } 26 \text { recorded taxa, but the occurrence } \\
\text { of Nitzschia spp. taxa and other representatives of higher trophy points out } \\
\text { the turn-over towards the eutrophic stage. } \\
\text { Conclusion: Grliska is in a more advanced stage of prolonged eutrophy } \\
\text { conditions. }\end{array}$ & \\
\hline
\end{tabular}




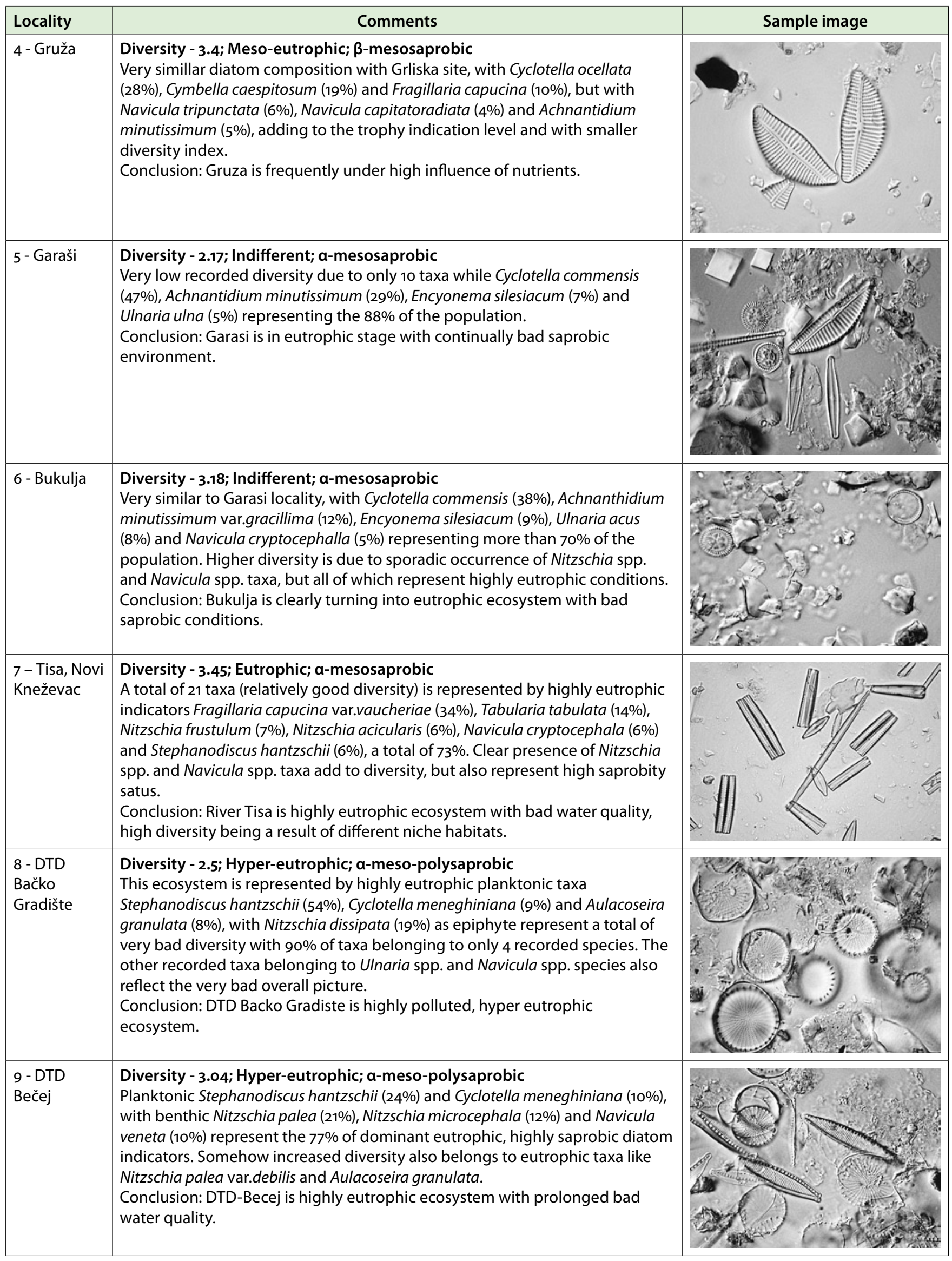




\begin{tabular}{|c|c|c|}
\hline Locality & Comments & Sample image \\
\hline 10 - Krivaja & $\begin{array}{l}\text { Diversity - 2.87; Eutrophic; a-mesosaprobic } \\
\text { This river is dominated by the attached taxa Planothidium lanceolatum ( } 27 \%) \text {, } \\
\text { Nitzschia frustulum ( } 20 \% \text { ) and Amphora normanii ( } 22 \%) \text {, a total of } 69 \% \text { of highly } \\
\text { eutrophic indicators. Low diversity also represents very bad overall ecological } \\
\text { status. } \\
\text { Conclusion: River Krivaja is highly polluted, eutrophic river. }\end{array}$ & \\
\hline $\begin{array}{l}11 \text { - DTD } \\
\text { Vrbas }\end{array}$ & $\begin{array}{l}\text { Diversity - 3.6; Eutrophic; } \beta \text {-mesosaprobic } \\
\text { This locality is more diverse in diatom flora with Nitzschia frustulum (20\%), } \\
\text { Amphora pediculus (11\%), Fragilaria capucina var. mesolepta (10\%) and } \\
\text { Stephanodiscus hantzschii (10\%) dominating. Occurrence of rare taxa such as } \\
\text { Navicula hintzii (5\%), Diatoma tenuis (9\%) or Amphora copulata (3\%) in fairly } \\
\text { good presence is a sign of more natural conditions. } \\
\text { Conclusion: DTD Vrbas is still eutrophic but diverse ecosystem with clear signs } \\
\text { of intensive purification processes. }\end{array}$ & \\
\hline $\begin{array}{l}12 \text { - DTD, } \\
\text { Ruski Krstur }\end{array}$ & $\begin{array}{l}\text { Diversity - 2.97; Eutrophic; a-meso-polysaprobic } \\
\text { Stephanodiscus hantzschii ( } 43 \%) \text { dominate at this locality followed by Cyclotella } \\
\text { meneghiniana (16\%) and Navicula erifuga (10\%) all representatives of highly } \\
\text { eutrophic habitats. Important presence of Nitzschia spp. and Navicula spp. } \\
\text { taxa indicators for high saprobity completely mask the sporadic single species } \\
\text { that increase the overall diversity on this site. } \\
\text { Conclusion: Ruski Krstur is highly eutrophic, bad water quality site in a } \\
\text { prolonged period. }\end{array}$ & \\
\hline $\begin{array}{l}13 \text { - DTD } \\
\text { Sombor }\end{array}$ & $\begin{array}{l}\text { Diversity - 3.88; Eutrophic; } \beta \text {-mesosaprobic } \\
\text { This site is dominated by the attached Cooconeis pediculus (18\%), Cocconeis } \\
\text { placentula var.lineata ( } 16 \%) \text {, Nitzschia frustulum (14\%) and Pseudostaurosira } \\
\text { brevistriata (10\%) like eutrophic and } \beta \text {-mesosaprobic taxa. Total diversity is } \\
\text { increased with significant presence of different eutrophic taxa and sporadic } \\
\text { (1-2\% abundance) indicators of good water status. } \\
\text { Conclusion: Sombor is eutrophic ecosystem in transition to constantly bad } \\
\text { water quality system in which less tolerant diatom taxa are striving for } \\
\text { survival. }\end{array}$ & \\
\hline $\begin{array}{l}14-\text { DTD } \\
\text { Srpski } \\
\text { Miletic }\end{array}$ & $\begin{array}{l}\text { Diversity - 3.5; Meso-eutrophic; } \beta \text {-mesosaprobic } \\
\text { Nitzschia fonticola (27\%), Nitzshia dissipata (13\%), Gomphonema parvulum } \\
\text { s.l. (10\%), Cocconeis palcentula var.lineata (10\%), with Navicula cryptotenella } \\
(8 \%) \text { and Achnanthidium minutissimum (6\%) doinate at this site. All represent } \\
\text { eutrophic conditions. Slightly increased presence of Cymbella spp. taxa } \\
\text { improves both the diversity and saprobity. } \\
\text { Conclusion: Srpski Miletic is in transition to eutrophic conditions with } \\
\text { continual bad water quality. }\end{array}$ & \\
\hline $\begin{array}{l}15 \text { - Provala } \\
\text { Vajska }\end{array}$ & $\begin{array}{l}\text { Diversity - 2.87; Eutrophic; } \beta \text {-mesosaprobic } \\
\text { Only } 3 \text { diatom species dominate this site: Epithemia sorex (32), Navicula } \\
\text { cryptotenella (27\%) and Rhopalodia gibba (15\%) with 74\%, all representatives } \\
\text { of eutrophic conditions. Significantly less abundant are Cocconeis placentula } \\
(5 \%) \text {, Navicula radiosa (4\%) and Nitzschia linearis ( } 3 \%) \text { but they also add to } \\
\text { eutrophic indicators. Low diversity is also within the taxa representatives of } \\
\text { the } \beta \text {-mesosaprobic water quality. } \\
\text { Conclusion: Vajska is in advanced stage of hyper eutrophication. }\end{array}$ & \\
\hline
\end{tabular}




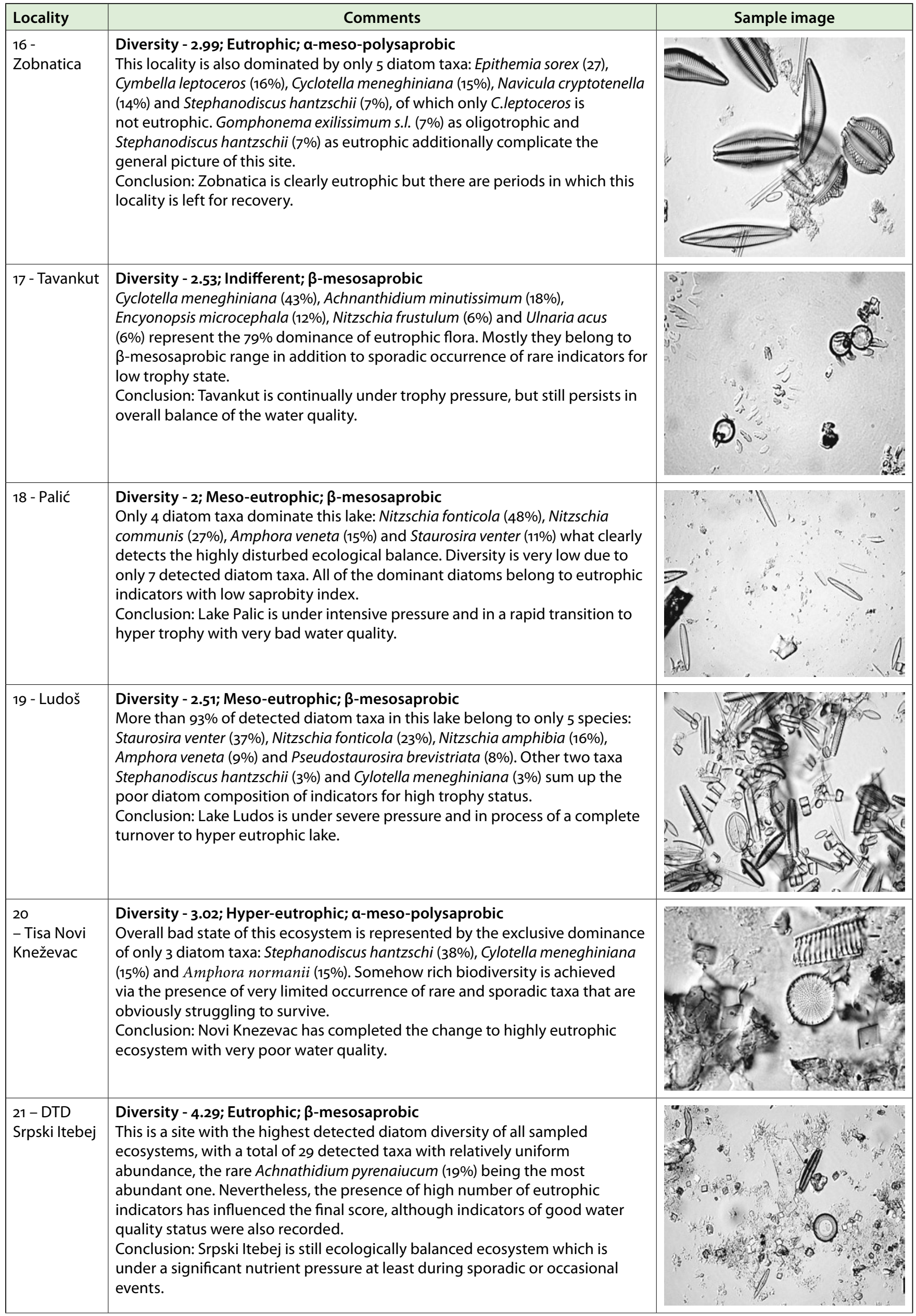




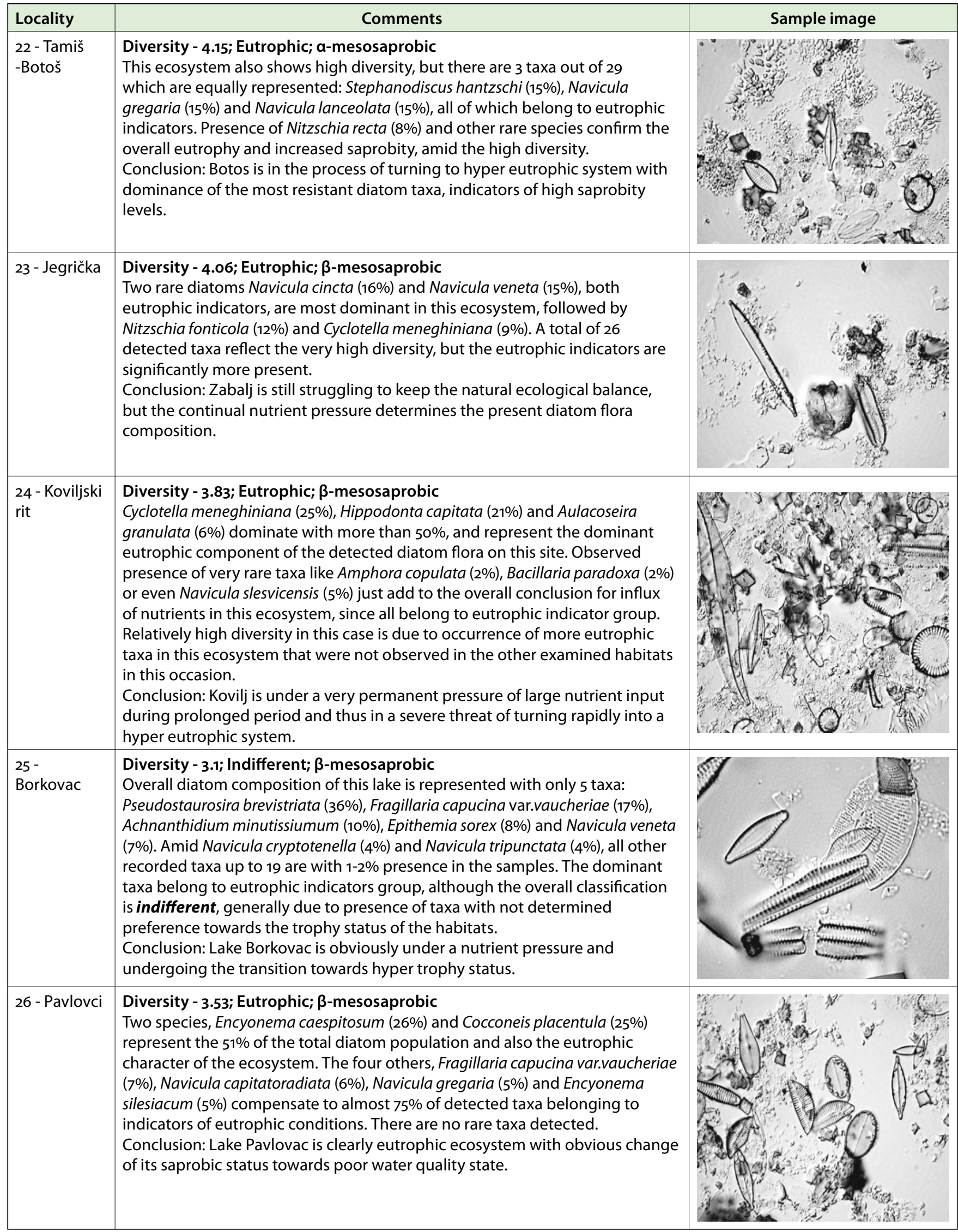


dance. With these results, the overall water quality deterioration in sampled water bodies has been confirmed during a prolonged time period, a conclusion in direct compliance to observed frequent "blooming" events during past 25 years. It can be expected that these eutrophication effects will be more frequent in future, since the majority of these water bodies were confirmed to be hyper-eutrophic, while the rest of them are rapidly undergoing the same change in ecological status. Contrary to confusing chemical results, not reliable WQI or Pantle-Buck indexes, diatom flora analysis is proven to be reliable and powerful method that, in combination with cyanobacteria, can produce important proofs both in direction of monitoring the deterioration of water ecosystems' quality or its improving when specific management techniques are applied.

As WFD (2000) recognizes the need for achieving the overall good water quality status in EU countries by 2015, the principle goal is to determine which Water Quality Objectives (WQO) shall be reached, monitored via indicators and maintained through a comprehensive River Basin Management Plans (also clearly defined in EU directives). Moss et al. (1993) define that "the higher standards are those which give maximum conservation value (those that maintain the highest potential habitat and species diversity), preserve functional values (such as fisheries, natural flood storage, harvesting or traditional products) and maintain high amenity". The principle question is now what approach should be used in defining the water quality objectives for the standing waters in Serbia? The approach accepted by the EC directives is based on so called "spatial state classification" where the quality state of defined water body is compared to a 'reference site' or a pristine ecosystem deprived form human influence. This system is further developed in a very complicated scheme of surveys and monitoring, the core focus given to pre-defined 'priority substances', and defining the reference conditions for every water body, what has already postulated very serious problems in reality.

On the other hand, there is a proposal by Moss et al. (1993) for so called 'state change approach' in which the present state is compared with a baseline for particular standing water body. In this case, the baseline reference is found in the historical development of that particular water body, mainly paleo-limnological research. This approach has multiple advantages in defining the overall water quality goals for the particular water body, like separating the natural from human induced eutrophication, avoiding the search for a reference site, profound and complicated chemical or biological research, introducing of any particular variable important for a specific water body and which can be traced either in the past data or informed opinion, etc.

If the second 'state change' approach is to be applied in defining and monitoring the water quality objectives in Serbia, there are several beneficial starting points confirmed also by the results presented in this work:

- Standing water ecosystems are very complex and dynamic systems influenced by geographical, morphometric, physical, chemical and biological variables, and potentially multiple interactions among them;

- The nature of the catchments is important in defining the nutritional status (mainly $\mathrm{N}$ and $\mathrm{P}$ content) regarding phytoplankton production;

- Overall, physical and chemical variables are more reliable descriptors of lake's state than community composition. But, as proven in this paper, diatom community structure and abundance more reliably reflects the prolonged trend in the water body;

- Sampling and comparison of variables should be quick and standardized. Biological material should be sampled easily and not relied on a specific standard habitat (like rocky littoral). The value of each variable must be comparable to the baseline data;

- Proposed variables by Moss et al. (1996) that meet the basic requirements include: water retention time, maximum depth, conductivity, inflow and lake total $\mathrm{N}$ and $\mathrm{P}$ concentrations, lake N:P ratio, Secchi depth, total alkalinity, $\mathrm{pH}$, lake calcium concentration, maximum phytoplankton Chl a concentration, plant score and potential for maintaining at least one fish species;

In the proposed variables for implementing of water quality methods for monitoring of eutrophication in standing waters of Serbia, obtained results in presented paper enable additional remarks:

- All water bodies should be considered as separate (not comparable) ecosystems - the "spatial change approach";

- All water bodies should be screened for the present and past trends in the basic eutrophication chemistry, with special attention to possible natural toxic background or increased eutrophication capacity;

- A basic set of monitoring variables should be established for every water body. These variables should reflect the catchment potential for eutrophication, but also the historical trend for that specific water body;

- Complicated biotic indexes should be avoided;
- Algae (diatoms and cyanobacteria) represent excellent water quality bio-indicators that can be traced in the past records of the water body and can easily reconstruct the historical trends of eutrophication;

- Any water body found in "blooming" with whatever alga species should be considered as highly eutrophic and regarded as potentially dangerous for any utilization. These water bodies demand extra attention and research regarding proper postulation of management plans and recovery activities.

\section{Conclusions}

Conducted survey of 26 water ecosystems, which were found with algal "blooms" at least once during the last 25 years, in Serbia in May 2007 revealed the following conclusions regarding the implementation of relevant water eutrophication monitoring system based on WFD principles:

- Water quality legislation and regulations in Serbia are out of date and not approximated to EU directives;

- Monitoring of the physic-chemical parameters in lotic and lentic environments is considered as basic for determination of the water quality. But, their relevance strongly depend on spatial and temporal changes, time of sampling, catchment, methodology used and applied classification system. Therefore, obtained results may be confusing and will not reflect the real eutrophication pattern of the specific water body;

- The basic relevance of increased eutrophication is focused primarily on the biota of the specific water body, than secondarily on the utilization of that water resource for human needs;

- There is an evident trend of decreasing of the water quality in almost all sampled ecosystems in presented survey, most of which have reached the stage of hyper eutrophic water bodies;

- Biotic indices, such as WQI or PantleBuck, have been proven erroneous in reaching the final conclusion of the water quality;

- The monitoring system should be based on 'state change approach' which considers any water body as a separate system with its own evolution and eutrophication patterns and does not need a reference site for monitoring the natural or anthropogenic eutrophication;

- Apart of basic surveillance monitoring which is very comprehensive and includes as many as possible (needed) parameters (geo-morphological, geological, physic, chemical, biological, etc.) for a specific water body and its catchment, the operational monitoring should be based on a 'easy to run' system with a 
few selected parameters and on algae as primary bio-indicator organisms. This system should also be open to any specific needs for the specific ecosystem, but also clear and simple for any decision maker or management body.

\section{Acknowledgements}

The authors would like to acknowledge the funding of the Ministry of Science and Environmental protection of the Serbian Government (project number: 146021B)

\section{References}

APHA 1992. Standard methods for the evaluation of water and wastewater. 18th edition, American Public Health Ass., USA.

APHA 1995. Standard methods for the examination of water and wastewater. $19^{\text {th }}$ edition. Washington, 1995.

Asbaek J., Valatka S. 2001. Surface water classification and implementation strategy. Technical Report No.1.1., DHI Water and Environment, Denmark and Lithuania, $55 \mathrm{pp}$.

Boon, P.J., Howell, D.L. 1997. Freshwater Quality: Defining the Indefinable? Sccottish natural heritage. Edinburgh.

Butcher, R. W. 1947. Studies in the ecology of rivers. IV. The algae of organically enriched water. Journal of Ecology 35, 186-191.

Cemagref 1982. Etude des méthodes biologiques quantitative d'appréciation de la qualité des eaux. Rapport Q.E. LyonA.F. Bassin Rhone-Méditerranée-Corse, Lyon, France.

Cox, E. J. 1991. What is the basis for using diatoms as monitors of river quality? In: Whitton BA, Rott E and Friedrich G (eds.) Use of algae for monitoring rivers. Institut für Botanik, Universität in Innsbruck, pp 33-40.

Dell'Uomo, A. 1996. L'indice diatomico di eutrofizzazione/polluzione (EPI-D) nel monitoraggio delle acque correnti. Linee guida.

Descy, J.-P., Coste, M. 1991. A test of methods for assessing water quality based on diatoms. Verhandlungen der internationale Vereinigung für theoretische und angewandte Limnologie 24: 2112-2116.

EC Parliament and Council, 200o. Directive of the European Parliament and of the Council 200o/6o/EC establishing a framework for community action in the field of water policy. European Commission PECONS 3639/1/100 Rev 1, Luxembourg.
Felföldy L. 1980. A biológiai vizminösités. 3. javitott és bövitte kiadás. Vizugyi Hydrobiologicalgia, 9. Budapest.

Kelly, M. G. 1998. Use of trophic diatom index to monitor eutrophication in rivers. Water Research 36: 236-242.

Kolkwitz, R., Marsson, M. 1908. Ökologie der pflanzliche Saprobien. Ber. Deutsche Bot. Gesellsch. 26: 505-519.

Krammer, K., Lange-Bertalot, H. 1986. Bacillariophyceae 1. Teil: Naviculaceae. In: Pascher A (ed.) Süsswasserflora von Mitteleuropa. Band 2/1, Gustav Fischer Verlag, Heidelberg, Berlin.

Krstić, S., Svirčev, Z., Levkov, Z., Nakov, T. 2007. Selecting appropriate bioindicator regarding the WFD guidelines for freshwaters - a Macedonian experience. International Journal on Algae 9, 41-63.

Lange-Bertalot, H. 200o. Iconographia Diatomologica. Annotated Diatom Micrographs Vol. 9. Koeltz Scientific Books. Königstein.

Lecointe, C., Coste, M., Prygiel, J. 1993. "OMNIDIA" software for taxonomy, calculation of diatom indices and inventories management. Hydrobiologia 269/270: 509-513.

Lenoir, A., Coste, M. 1996. Development of a practical diatomic index of overall water quality applicable to the French National Water Board Network. In: Rott, E. (ed.) 2nd Workshop on Algae for Monitoring Rivers, Innsbruck 18-19 Sept. 95, Studia Student. G.m.b.H., Innsbruck.

Matavulj, M. 1986. The non-specific phospho-monoester-hydrolases of microorganisms and their significance in phosphorus cycle in aquatic environments. PhD Thesis, University of Zagreb.

Mitchell, M., William, S. 1995. Field Manual for Water Quality Monitoring, $9^{\text {th }}$ Ed. Thomson-Shore Printers: Dexter, Michigan.

Moss, B., Johnes, P., Phyllips, G. 1993. New approaches to monitoring and classifying standing waters. Ecological Monographs, 118-133.

Moss, B., Johnes, P., Phyllips, G. 1996. The monitoring of ecological quality and classification of standing waters in temperate regions: a review and proposal based on a worked scheme for British waters. Biological Reviews, 71, 301-319.

OECD, 1982. Eutrophication of waters. Monitoring, assessment and control. Paris. pp. 155

Pantle, R., Buck, H. (1955): Biologische Ueberwachung der Gewasser und die Dar- stellung der Ergenisse. Gas Wasserfach 96/18:604.

Prygiel, J., Coste, M. 200o. Guide Méthodologique pour la mise en oeuvre de l'Indice Biologique Diatomées. NF T 90-354. Etude Agences de l'Eau-Cemagref Bordeaux, March 2000, Agences de l'Eau. pp. 134

Reynolds, C.S. 1992: Eutrophication and the management of planktonic algae: what Vollenweider couldn't tell us. In: Eutrophication and management of planktonic algae (D.W. Sutcliffe and J.G.Jones eds.). Freshwater Biological Association, Ambleside. 4-29.

Round, F. E., 1991. Use of diatoms for monitoring rivers. In: Whitton, B.A., E. Rott \& G. Friedrich (eds), Use of Algae for Monitoring Rivers. Düsseldorf: 25-32.

Ryding, S.O., Rast, W.(eds.) 1989. The control of eutrophication of lakes and reservoirs. Man and Biosphere Series, Vol. I, 314 pp.

Rumeau, A., Coste, M. 1988. Initiation a la systematique des Diatomees d'eau douce pour l'utilisation pratique d'un indice diatomique generique. Bulletin Francais de la peche et de la Pisciculture 309: 1-69.

Shannon, C.E. , Wiever, W. 1949. The Mathematical theory of Communication. University of Illinois Press, Urbana, $125 \mathrm{pp}$.

Simeunović, Z., Svirčev, Z., Krstić, S., Lazić, L. 2005. Occurrence of cyanobacterial blooms in Vojvodina water ecosystems. Geographica Pannonica 9, 13-19.

Van Dam, H., Mertens, A., Sinkeldam, J. 1994. A coded checklist and ecological indicator values of freshwater diatoms and ecological indicator values of freshwater diatoms from Netherland. Netherland Journal of Aquatic Ecology 28: 117-133.

Veljković, N., Jovičić, M. 2006. Water quality analysis of reservoirs in Serbia in relation to target values of $75 / 440 / E E C$ directive. Proceedings of Conference "Water 2006", June 6-9, 2006, Zlatibor, Serbia.

Washington, H.G. 1980. Diversity, biotic and similarity indices - a review with special relevance to aquatic ecosystems. Water Research 18, 653-694.

Wetzel, R. G. 1983. Limnology. Saunders College Publishing, New York. 858 pp.

$\mathrm{Wu}$, J.-T. 1999. A generic index of diatom assemblages as bioindicator of pollution in the Keelung River of Taiwan. Hydrobiologia 397: 79-87. 